\title{
SUMMARY OF LITHOLOGIC LOGGING OF NEW AND EXISTING BOREHOLES AT YUCCA MOUNTAIN, NEVADA, MARCH 1994 TO JUNE 1994
}

\author{
by Jeffrey K. Geslin and Thomas C. Moyer
}

\section{U.S. GEOLOGICAL SURVEY}

Open-File Report 94-451

Prepared in cooperation with the

NEVADA OPERATIONS OFFICE,

U.S. DEPARTMENT OF ENERGY under

Interagency Agreement DE-Al08-92NV10874

\section{DISCLAIMER}

This report was prepared as an account of work sponsored by an agency of the United States Government. Neither the United States Government nor any agency thereof, nor any of their employees, makes any warranty, express or implied, or assumes any legal liability or responsibility for the accuracy, completeness, or usefulness of any information, apparatus, product, or process disclosed, or represents that its use would not infringe privately owned rights. Reference herein to any specific commercial product, process, or service by trade name, trademark, manufacturer, or otherwise does not necessarily constitute or imply its endorsement, recommendation, or favoring by the United States Government or any agency thereof. The views and opinions of authors expressed herein do not necessarily state or reflect those of the United States Government or any agency thereof.

\section{Denver, Colorado} 1995 


\title{
U.S. DEPARTMENT OF THE INTERIOR BRUCE BABBITT, Secretary
}

\author{
U.S. GEOLOGICAL SURVEY
}

Gordon P. Eaton, Director

The use of trade, product, industry, or firm names is for descriptive purposes only and does not imply endorsement by the U.S. Government.

For additional information write to: Chief, Earth Science Investigations Program

Yucca Mountain Project Branch

U.S. Geological Survey

Box 25046, MS 421

Denver Federal Center

Denver, CO 80225
Copies of this report can be purchased from: U.S. Geological Survey

Earth Science Information Center

Open-File Reports Section

Box 25286, MS 517

Denver Federal Center

Denver, CO 80225 


\section{DISCLAIMER}

Portions of this document may be illegible in electronic image products. Images are produced from the best available original document. 


\section{CONTENTS}

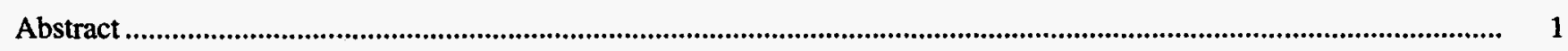

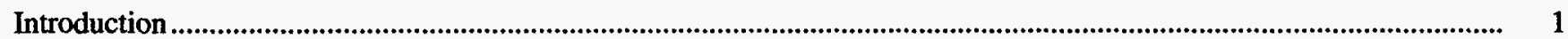

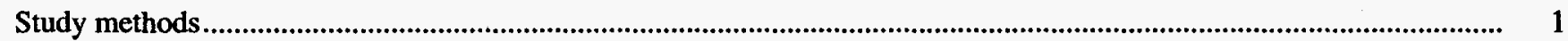

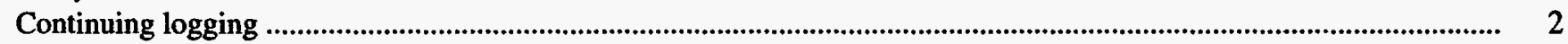

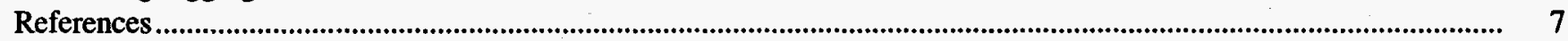

Appendix 1. Graphical lithologic logs for boreholes at Yucca Mountain, Nevada ..................................................... 10

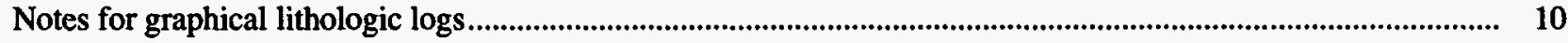

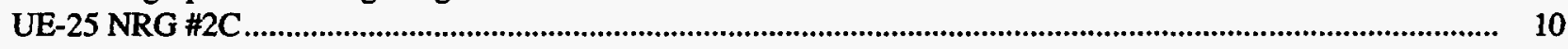

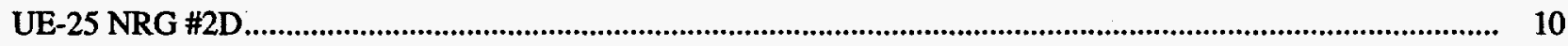

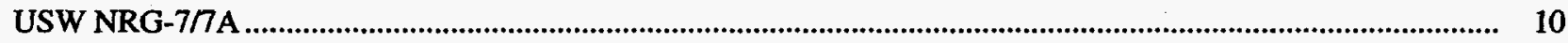

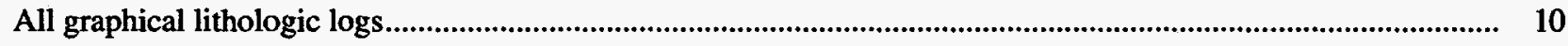

\section{FIGURES}

1. Borehole location map.

\section{TABLES}

1. Location and information for boreholes logged at Yucca Mountain, March 1994 to June 1994.............................

2. Lithostratigraphic nomenclature of the Paintbrush Group at Yucca Mountain ...................................................

3. Generalized lithostratigraphy of boreholes at Yucca Mountain, Nevada...........................................................

4. Summary of depths to basal contacts for boreholes at Yucca Mountain, Nevada ............................................... 6

\section{CONVERSION FACTORS AND VERTICAL DATUM}

\begin{tabular}{rll}
\hline Multiply & By & To obtain \\
& & \\
millimeter $(\mathrm{mm})$ & 0.03937 & inch \\
centimeter $(\mathrm{cm})$ & 0.3937 & inch \\
meter $(\mathrm{m})$ & 3.281 & foot \\
kilometer $(\mathrm{km})$ & 0.6214 & mile \\
\hline
\end{tabular}

Sea level: In this report "sea level" refers to the National Geodetic Vertical Datum of 1929 (NGVD of 1929)-a geodetic datum derived from a general adjustment of the first-order level nets of both the United States and Canada, formerly called Sea Level Datum of 1929. 


\title{
Summary of Lithologic Logging of New and Existing Boreholes at Yucca Mountain, Nevada, March 1994 to June 1994
}

\author{
By Jeffrey K. Geslin andThomas C. Moyer
}

\section{Abstract}

This report summarizes lithologic logging of core from boreholes at Yucca Mountain, Nevada, conducted from March 1994 to June 1994. Units encountered during logging include Quaternary-Tertiary alluvium and colluvium, Tertiary Rainier Mesa Tuff, all units in the Tertiary Paintbrush Group, and Tertiary Calico Hills Formation. Logging results are presented in a table of contact depths for core from unsaturated zone neutron (UZN) boreholes and graphic lithologic logs for core from north ramp geology (NRG) boreholes.

\section{INTRODUCTION}

Yucca Mountain, Nevada, is being investigated as a potential site for a high-level radioactive waste repository. This report summarizes the lithologic logging of new and existing boreholes at Yucca Mountain that was done from March to June 1994, by the Yucca Mountain Project Branch of the U.S. Geological Survey (USGS). This logging was undertaken with the objective to determine the spatial distribution and characteristics of stratigraphic units within the Yucca Mountain site area. Stratigraphic data obtained from lithologic logging are used in a preliminary threedimensional lithostratigraphic model of Yucca Mountain. These data also can be integrated into hydrologic studies at Yucca Mountain and applied to engineering and construction of the Exploratory Studies Facility.

Lithostratigraphic units identified during logging include Quaternary-Tertiary alluvium and colluvium, the Tertiary Rainier Mesa Tuff of the Timber Mountain Group, all units in the Tertiary Paintbrush Group, and the Tertiary Calico Hills Formation. Criteria used to identify contacts between these units, and between lithostratigraphic units within the Paintbrush Group, are discussed in Geslin and others (in press). Stratigraphic nomenclature and lithologic descriptions of stratigraphic units in the Tiva Canyon, Yucca Mountain, Pah Canyon, and Topopah Spring Tuffs of the Paintbrush Group are from Sawyer and others (in press) and also are summarized in Buesch and others (USGS, written commun., 1994).

The boreholes logged from March to June 1994 are listed, with their location and elevation, in table 1. Table 1 also lists the Data Tracking Number (DTN) for stratigraphic data from each borehole that have been released to the Yucca Mountain Project, submitted to the USGS Local Records Center in Denver, Colorado, and stored in the Yucca Mountain Project Central Records Facility in Las Vegas, Nevada. The locations of these boreholes are shown in figure 1. Cores from boreholes logged during this study are stored at the Yucca Mountain Project Sample Management Facility at the Nevada Test Site.

\section{STUDY METHODS}

Lithostratigraphic units identified in core follow the stratigraphic hierarchy and nomenclature for the Paintbrush Group defined in Sawyer and others (in press) and followed by Buesch and others (USGS written commun., 1994) (table 2). The criteria used to identify contacts between stratigraphic units are described in Geslin and others (in press). Lithologic logging includes either identification of the depths of stratigraphic contacts (herein referred to as type 1 logging) or identification of the depths of contacts and detailed unit descriptions (herein referred to as type 2 logging). The lithostratigraphic units encountered during type 1 and type 2 logging of core from boreholes are summarized in table 3 . The results of type 1 logging are reported as tables of contact depths (summarized in table 4), whereas the results of type 2 logging are reported in graphical form (appendix 1).

Type 1 logs were completed for core recovered from unsaturated zone neutron (UZN series) boreholes (table 4). Core recovered from UZN-series boreholes is stored in lexan tubing that limits viewing of the core and modifies colors by retaining moisture. Contacts that are difficult to identify through lexan or that were removed by sampling were confirmed or constrained by examination of processed samples at the Hydrologic Research Facility or by viewing videotapes of core photographed prior to sample removal. 
Table 1. Location and information for boreholes logged at Yucca Mountain, March 1994 to June 1994

[Northing, easting, and elevation data are from EG\&G and were provided as information to the Yucca Mountain Project. Northing and easting are based on the Nevada State Coordinate System. Locations and elevations are in feet.]

\begin{tabular}{|c|c|c|c|c|}
\hline Borehole number & Northing & Easting & Elevation & Data tracking number \\
\hline \multicolumn{5}{|c|}{ Identification of lithologic contacts (type 1 logging) } \\
\hline USW UZ-N11 & $780,573.93$ & $559,020.93$ & $5,224.0$ & GS940308314211.010 \\
\hline USW UZ-N15 & $778,090.54$ & $559,551.76$ & $5,109.4$ & GS940308314211.019 \\
\hline USW UZ-N16 & $778,150.80$ & $559,625.98$ & $5,116.6$ & GS940308314211.019 \\
\hline USW UZ-N17 & $778,224.12$ & $559,995.10$ & $5,127.9$ & GS940308314211.019 \\
\hline USW UZ-N36 & $773,899.50$ & $563,582.66$ & $4,642.0$ & GS940308314211.018 \\
\hline USW UZ-N38 & $767,466.37$ & $563,343.41$ & $4,148.9$ & GS940308314211.011 \\
\hline UE-25 UZN \#63 & $768,836.54$ & $566,169.39$ & $3,944.1$ & GS940308314211.017 \\
\hline USW UZ-N64 & $765,728.46$ & $559,435.76$ & $4,790.9$ & GS940308314211.016 \\
\hline \multicolumn{5}{|c|}{ Detailed lithologic logging (type 2 logging) } \\
\hline UE-25 NRG \#2C & $765,771.68$ & $569,189.76$ & $3,801.2$ & GS940308314211.012 \\
\hline UE-25 NRG \#2D & $765,825.10$ & $569,132.29$ & $3,792.1$ & GS940308314211.013 \\
\hline USW NRG-7A & $768,879.96$ & $562,984.13$ & $4,207.0$ & GS940408314211.020 \\
\hline
\end{tabular}

Type 2 lithologic logs (appendix 1) were created for core recovered from north ramp geology (NRG) boreholes. These logs use the criteria of Buesch and others (USGS, written commun., 1994) to identify the welding and crystallization zones in each unit. Accompanying lithologic unit descriptions include the phenocryst content and assemblage; lithophysae content and size; pumice content, size, and composition; lithic clast content, size, and composition; and matrix color and content. The percentage of phenocrysts, lithic clasts, pumice clasts and lithophysae are visually estimated using charts included in the Munsell Soil Color Charts (Kollmorgen Instruments Corp., 1992). Phenocryst, pumice, and lithic clast types are identified with the aid of a hand lens. Phenocryst, pumice, and lithic clast types are identified with the aid of a hand lens or binocular microscope. The maximum and minimum dimensions of pumice, lithic clast, and lithophysae (void) sizes are measured along two perpendicular axes and recorded as either typical or maximum sizes observed. Pumice, lithic clast, and matrix colors are determined on dry core using Munsell Color Charts
(Geological Society of America, 1991; Kollmorgen Instruments Corp., 1992). Other features of the core, including fracture geometry and morphology, fracture mineralization, and development and orientation of foliation (dip angle measured from horizontal), also are recorded and included in unit descriptions.

\section{CONTINUING LOGGING}

Continued logging in 1994 and 1995 will produce a table of contact depths for boreholes NRG \#5A, SD-9, SD-10, SD-12, UZ-7A, SRG-1, SRG-2, SRG-3, and SRG-4 (depending on drilling progress) that will be submitted to the USGS Yucca Mountain Project Branch Local Records Center upon completion of drilling and following internal review. Graphical lithologic logs that summarize detailed logging will be prepared for UZ-14, SD-9, SD-12, and UZ-7A (depending on drilling progress). These data will be integrated into the preliminary three-dimensional lithostratigraphic model of Yucca Mountain. 


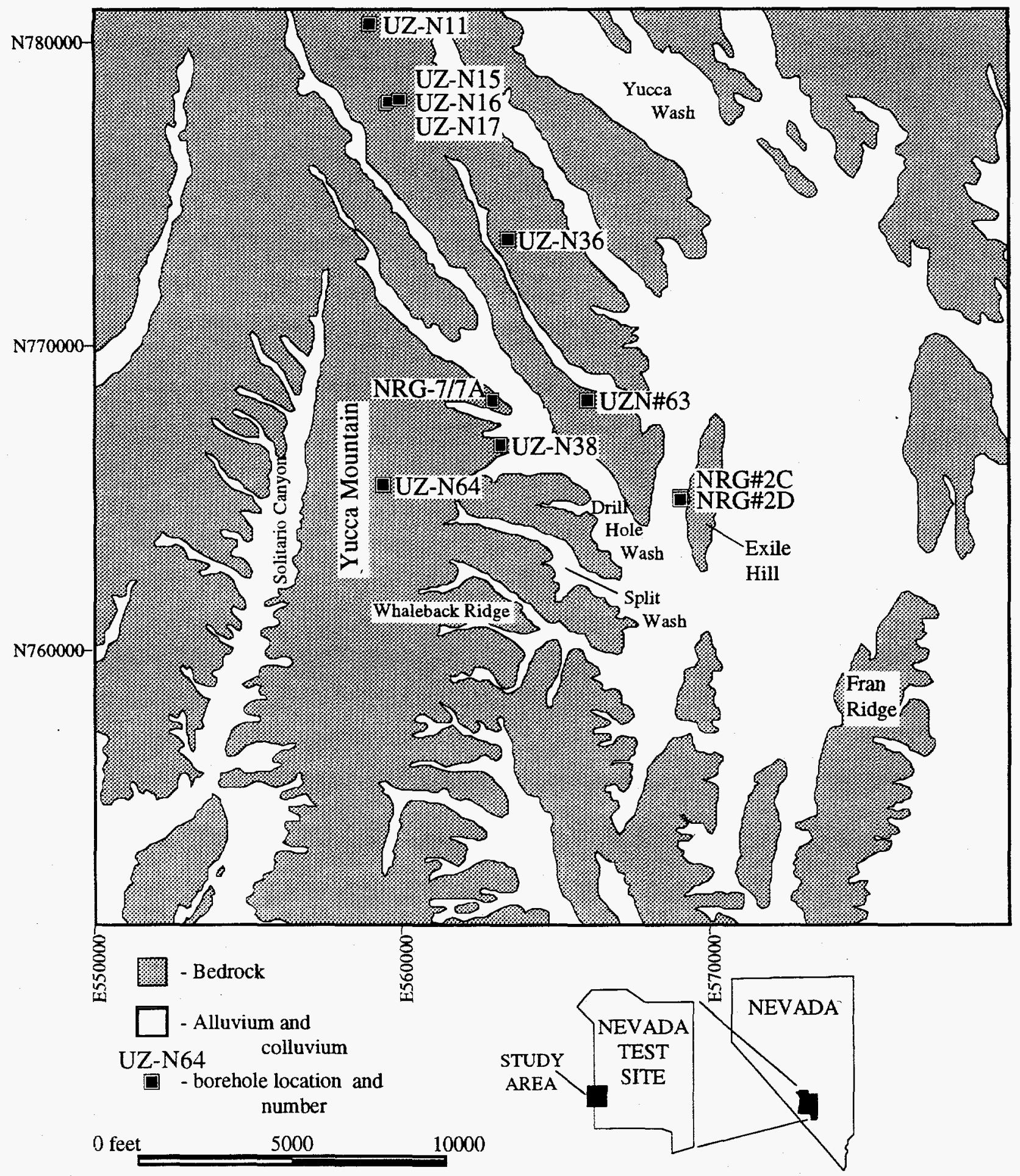

Figure 1. Borehole location map (modified from Nelson and others, 1991). 
Table 2. Lithostratigraphic nomenclature of the Paintbrush Group at Yucca Mountain (from Sawyer and others, in press; Buesch and others, USGS, written commun., 1994)

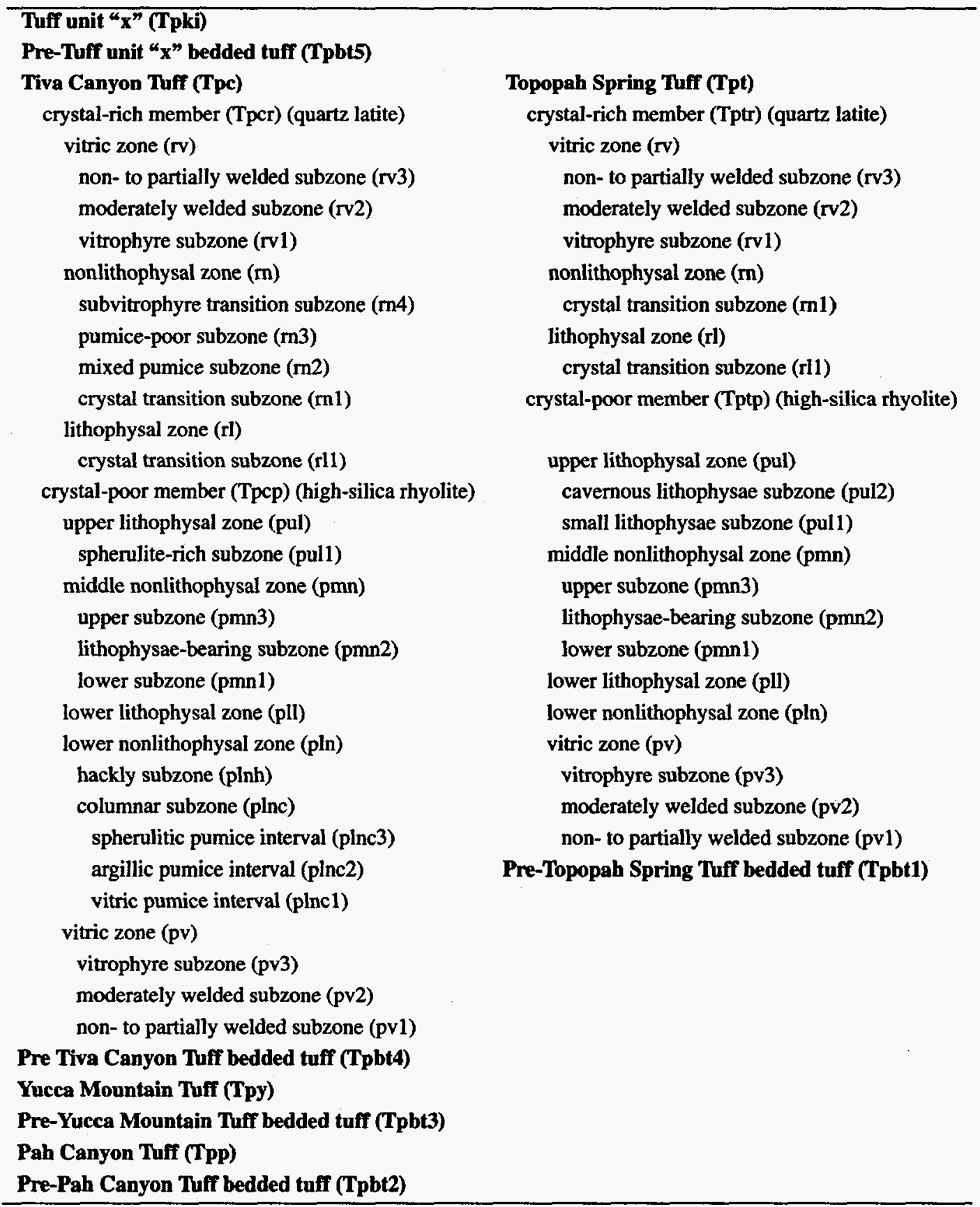




\begin{tabular}{|c|c|c|c|c|c|c|c|c|c|c|c|}
\hline & \multicolumn{11}{|c|}{ Borehole number } \\
\hline & UZ-N 11 & UZ-N 15 & UZ-N 16 & UZ-N 17 & UZ-N 36 & UZ-N 38 & UZN $* 63$ & UZ-N 64 & NAG $\# 2 C$ & NRG \#2D & $\begin{array}{l}\text { NRG } \\
-\pi \Pi \mathrm{A}\end{array}$ \\
\hline \multicolumn{12}{|l|}{ Rainier Mesa Tuff (Tmr) } \\
\hline \multicolumn{12}{|l|}{ Pre-Rainier Mesa Tuff bedded tuff (Tmbt1) } \\
\hline \multirow{2}{*}{\multicolumn{12}{|c|}{ Tuff unit " $\mathrm{x}$ " (Tpki) }} \\
\hline Pre-Tuff unit " $x$ " bedded tuff (Tpbt5) & & & & & & & & & & & \\
\hline \\
\hline & & & & & & & & & & & \\
\hline \multicolumn{12}{|l|}{ vitric zone (rv) } \\
\hline nonlithophysal zone (m) & & I & $I$ & I & I & & & I & & & \\
\hline \multicolumn{12}{|l|}{ lithophysal zone (rl) } \\
\hline \multicolumn{12}{|l|}{ crystal-poor member (Tpcp) } \\
\hline \multicolumn{12}{|l|}{ upper lithophysal zone (pul) } \\
\hline \multicolumn{12}{|l|}{ middle nonlithophysal zone (pmn) } \\
\hline \multicolumn{12}{|l|}{ lower lithophysal zone (pll) } \\
\hline \multicolumn{12}{|l|}{ lower nonlithophysal zone (pln) } \\
\hline \multicolumn{12}{|l|}{ hackly subzone (plnh) } \\
\hline \multicolumn{12}{|l|}{ columnar subzone (pinc) } \\
\hline \multicolumn{12}{|l|}{ vitric zone (pv) } \\
\hline \multicolumn{12}{|l|}{ Pre-Tiva Canyon Tuff bedded tuff (Tpbt4) } \\
\hline \multicolumn{12}{|l|}{ Yucca Mountain Tuff (Tpy) } \\
\hline \multicolumn{12}{|l|}{ Pre-Yucca Mountain Tuff bedded tuff (Tpbt3) } \\
\hline \multicolumn{12}{|l|}{ Pah Canyon Tuff (Tpp) } \\
\hline \multicolumn{12}{|l|}{ Pre-Pah Canyon Tuff bedded tuff (Tpbt2) } \\
\hline \multicolumn{12}{|l|}{ Topopah Spring Tuff (Tpt) } \\
\hline \multicolumn{12}{|l|}{ crystal-rich member (Tptr) } \\
\hline \multicolumn{12}{|l|}{ vitric zone (rv) } \\
\hline nonlithophysal zone (m) & & & & & & & & & & & \\
\hline lithophysal zone (rl) & & & & & & & & & & & \\
\hline crystal-poor member (Tptp) & & & & & & & & & & & \\
\hline upper lithophysal zone (pul) & & & & & & & & & & & \\
\hline middle nonlithophysal zone (pmn) & & & & & & & & & & & \\
\hline lower lithophysal zone (pll) & & & & & & & & & & & \\
\hline lower nonlithophysal zone (pln) & & & & & & & & & & & \\
\hline vitric zone (pv) & & & & & & & & & & & \\
\hline Pre-Topopah Spring Tuff bedded tuff (Tpbt1) & & & & & & & & & & & \\
\hline Calico Hills Formation (Tac) & & & & & & & & & & & \\
\hline
\end{tabular}


Table 4. Summary of depths to basal contacts for boreholes at Yucca Mountain, Nevada

\begin{tabular}{|c|c|c|c|c|c|c|c|c|}
\hline UNIT* no core & $\begin{array}{c}\text { USW } \\
\text { UZ-N11 }\end{array}$ & $\begin{array}{c}\text { USW } \\
\text { UZ-N15 }\end{array}$ & $\begin{array}{c}\text { USW } \\
\text { UZ-N16 }\end{array}$ & $\begin{array}{l}\text { USW } \\
\text { UZ-N17 }\end{array}$ & $\begin{array}{c}\text { USW } \\
\text { UZ-N36 }\end{array}$ & $\begin{array}{c}\text { USW } \\
\text { UZ-N38 }\end{array}$ & $\begin{array}{l}\text { UE-25 } \\
\text { UZN \#63 }\end{array}$ & $\begin{array}{c}\text { USW } \\
\text { UZ-N64 }\end{array}$ \\
\hline Alluvium/colluvium (QTac) & 1.7 & 2.3 & 4.2 & 2.5 & 0.9 & 17.9 & 4.4 & 1.8 \\
\hline Tiva Canyon Tuff (Tpc) & & & & & & & $8.6+$ & \\
\hline \multicolumn{9}{|l|}{ crystal-rich member (Tpcr) } \\
\hline \multicolumn{9}{|l|}{ nonlithophysal zone (m) } \\
\hline subvitrophyre transition subzone (m4) & & $16.2 \dagger$ & & $19.3 \dagger$ & $16.1 \dagger$ & & & \\
\hline pumice-poor subzone (rn3) & & 57.6 & $36.5+$ & & 47.5 & & & \\
\hline mixed pumice subzone $(\mathrm{m} 2)$ & & & & & & & & $39.8 \dagger$ \\
\hline \multicolumn{9}{|l|}{ crystal transition subzone (m1) } \\
\hline \multicolumn{9}{|l|}{ crystal-poor member (Tpcp) } \\
\hline \multicolumn{9}{|l|}{ lower nonlithophysal zone (pln) } \\
\hline hackly subzone (plnh) & & & & & & $27.3 \dagger$ & $25.0+\dagger$ & \\
\hline \multicolumn{9}{|l|}{ columnar subzone (plnc) } \\
\hline spherulitic pumice interval (c3) & & & & & & 49.1 & 44.3 & \\
\hline argillic pumice interval (c2) & $25.2 \dagger$ & & & & & 80.9 & & \\
\hline \multicolumn{9}{|l|}{ vitric zone (pv) } \\
\hline moderately welded subzone (pv2) & 29.7 & & & & & & & \\
\hline non- to partially welded subzone (pv1) & 46.4 & & & & & & & \\
\hline Bedded tuff (Tpbt4) & 60.6 & & & & & & & \\
\hline \multicolumn{9}{|l|}{ Yucca Mountain Tuff (Tpy) } \\
\hline Total depth & 84.4 & 59.9 & 60.0 & 59.9 & 59.8 & 89.4 & 60.0 & 60.0 \\
\hline
\end{tabular}

* Stratigraphic subdivisions follow the nomenclature defined by Buesch and others (USGS, written commun., 1994). All measurements are in feet.

$\dagger$ The first unit encountered in the borehole.

$\dagger †$ The contact between the hackly and columnar subzones of the crystal-poor lower nonlithophysal zone is gradational from 25.0 to 37.3 feet. This unit is overlain by alluvium or colluvium. 


\section{REFERENCES}

Geological Society of America, 1991, Rock-color chart: Boulder, Colo., Geologic Society of America. (MOL.19940810.0002)

Geslin, J.K., Moyer, T.C., and Buesch, D.C., 1994, Summary of lithologic logging of new and existing boreholes at Yucca Mountain, Nevada, August 1993 to February 1994: U.S. Geological Survey Open-File Report 94-342, in press. (MOL.19940810.0011)

Kollmorgen Instruments Corporation, 1992, Munsell soil color charts: New York, Kollmorgen Instruments Corporation. (MOL.19940810.0003)

Nelson, P.H., Muller, D.C., Schimschal, Ulrich, and Kibler, J.E., 1991, Geophysical logs and core measure- ments from forty boreholes at Yucca Mountain, Nevada: U.S. Geological Survey, Geophysical Investigations Map GP-1001, 64 p. (NNA.920211.0022)

Sawyer, D.A., Fleck, R.J., Lanphere, M.A., Warren, R.G., Broxton, D.E., and Hudson, M.R., Episodic caldera volcanism in the Miocene southwestern Nevada volcanic field-Revised stratigraphic framework, ${ }^{40} \mathrm{Ar} /{ }^{39} \mathrm{Ar}$ geochronology, and implications for magmatism and extension: Geological Society of America Bulletin, in press. (MOL.19940725.0004)

NOTE: Parenthesized numbers following each cited reference are for U.S. Department of Energy OCRWM Records Management purposes only and should not be used when ordering the publication. 

APPENDIX 


\section{APPENDIX 1. GRAPHICAL LITHOLOGIC LOGS FOR BOREHOLES AT YUCCA MOUNTAIN, NEVADA}

\section{Notes for Graphical Lithologic Logs}

\section{UE-25 NRG \#2C}

Core was recovered from the borehole with a hollow-stem auger, and includes nonlithified pyroclastic-flow and fall deposits of the Rainier Mesa Tuff (Timber Mountain Group), nonlithified bedded tuffs that underlie Rainier Mesa Tuff, and lithified tuff unit " $x$ " (Paintbrush Group).

\section{UE-25 NRG \#2D}

Core that was recovered from the borehole with a hollow-stem auger includes nonlithified pyroclasticflow and fall deposits of the Rainier Mesa Tuff (Timber Mountain Group), nonlithified bedded tuffs that underlie Rainier Mesa Tuff, and lithified tuff unit " $x$ " (Paintbrush Group).

\section{USW NRG-7/7A}

NRG-7 is a vertical hole located at approximately $768,846.20 \mathrm{~N} ; 563,004.90 \mathrm{E}$ that was drilled from the surface to $17.0 \mathrm{ft}$ and then abandoned. NRG-7A is an adjacent vertical hole located at approximately $768,879.96 \mathrm{~N} ; 562,984.13 \mathrm{E}$ that was cored from 17.0 to $1513.4 \mathrm{ft}$ (total depth). Samples were collected from NRG-7, however, it is not known if these samples represent colluvium or bedrock. Therefore, surface to $17 \mathrm{ft}$ depth was not included in this log. Lithostratigraphic units in the core include the lower zones of the Tiva Canyon Tuff, Yucca Mountain Tuff, Pah Canyon Tuff, Topopah Spring Tuff, interbedded nonwelded tuffs of the Paintbrush Group, and the upper part of the Calico Hills Formation.

(V) - Contacts depths designated with this symbol were identified using videotape of the core prior to sample removal.

*-The top of the Topopah Spring Tuff is typically marked by a 2-cm-thick lithic-rich fallout deposit. This deposit apparently is represented by an unrecovered interval at approximately $280 \mathrm{ft}$. This depth is estimated from stratigraphic relationships in adjacent NRG boreholes.

\section{All Graphical Lithologic Logs}

\section{Welding Definitions}

Nonwelded $=$ nondeformed pumice, no to slight sintering of matrix.

Partially welded $=$ nondeformed pumice, sintered/ incipiently welded matrix (some macroscopic porosity).

Moderately welded $=$ partial deformation of pumice (some macroscopic porosity), densely welded matrix (no porosity).

Densely welded = collapsed pumice (no macroscopic porosity), densely welded matrix.

\section{Mineral Notation}

qtz = quartz

san $=$ sanidine

plag $=$ plagioclase

feld $=$ sanidine and plagioclase, undifferentiated

hbld $=$ hornblende

cpx $=$ clinopyroxene

bio $=$ biotite

(oxy)bio = partially oxidized biotite

oxybio $=$ completely oxidized biotite 


\section{Zones of welding (W)}

Moderately to Densely (o-lithophysae)

Partially to Moderately

Non- to Partially

Nonwelded

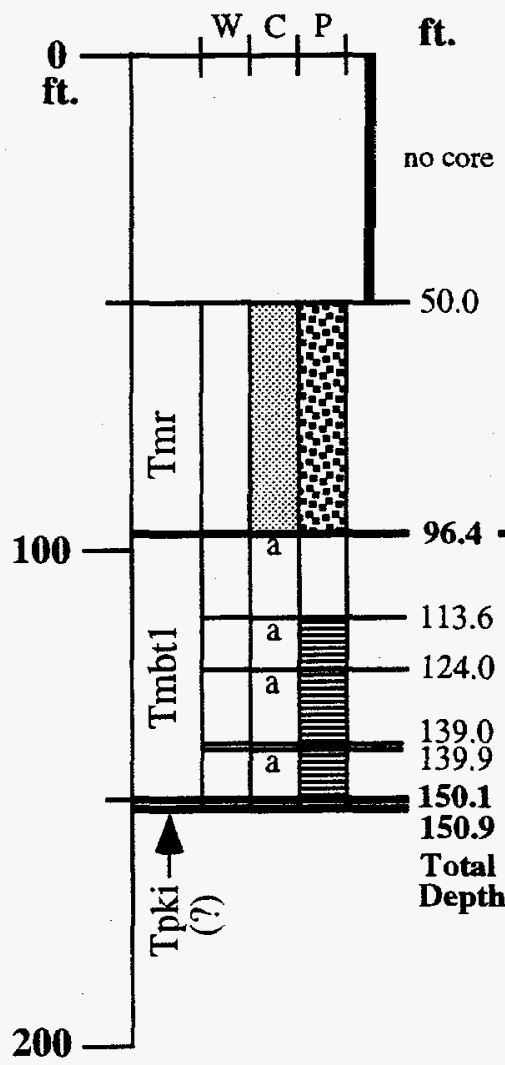

\section{Zones of crystallization (C)}

Devitrified / Devit. + vapor-phase mins.

Vitric / Vitric + vapor-phase mins.

Altered (a) / to clay (c) / to zeolite (z)

\section{Phenocryst content $(\mathbf{P})$}

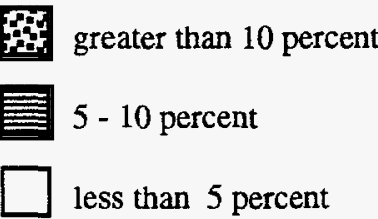

\section{Rainier Mesa Tuff (Tmr) -}

Nonithified pyroclastic-flow deposit: 50.0-96.4 ft

Matrix, which changes downward from pale yellowish brown to pinkish white, contains distinctive colorless, bubble-wall glass shards. Pumice clasts (10-15 percent) are vitric, colorless, light gray, light brown, or brownish orange. Crystals (10-15 percent) include qtz, plag, san, and bio. Deposit may be lithified above $51.5 \mathrm{ft}$.

\section{Bedded Tuff (Tmbt1) -}

96.4-113.6 ft: Nonlithified fallout tephra. White, vitric pumice lapilli and volcanic lithic clasts. Moderately sorted. Lithic content is $10-20$ percent above $108.5 \mathrm{ft}$, but less than 2 percent below $108.5 \mathrm{ft}$. Pumice clasts are typically less than $3 \mathrm{~mm}$ diameter. Grades upward into a light brown paleosol (96.4-100.8 ft). 113.6-124.0 ft: Nonlithified pumice-rich fallout. Moderately well sorted, normally graded. Pumice grades upward from less than $5 \mathrm{~mm}$ to less than $3 \mathrm{~mm}$ diameter. Contains grayish yellow-green lithic clasts. Crystals of feld, qtz, bio. Light brown paleosol from 113.6-118.8 ft. 124.0-139.9 ft: Nonlithified pyroclastic-flow (?) deposit. Light brown with glass shards and white pumice less than $5 \mathrm{~mm}$. Crystals of feld, qtz, bio. Pumice fallout from 139.0 to $139.9 \mathrm{ft}$. 139.9-150.1 ft: Nonlithified pyroclastic-flow (?) deposit. Medium brown with glass shards and 10-20 percent white pumice, most less than $5 \mathrm{~mm}$. Crystals of feld, qtz, bio. Poorly consolidated.

Tuff Unit "x" (Tpki) (?) -

Lithified pyroclastic-flow deposit: 150.1 ft-Total Depth

Pumice clasts (10-15 percent), white to pale yellowish or greenish (zeolitized?), in a brownish gray altered matrix. Volcanic lithic clasts (5-7 percent) are dark gray, dark reddish gray, or medium light gray. 
Borehole : UE-25 NRG \#2D

Data Tracking Number: GS940308314211.013

\section{Zones of welding (W)}

Moderately to Densely (o-lithophysae)

Partially to Moderately

Non- to Partially

Nonwelded

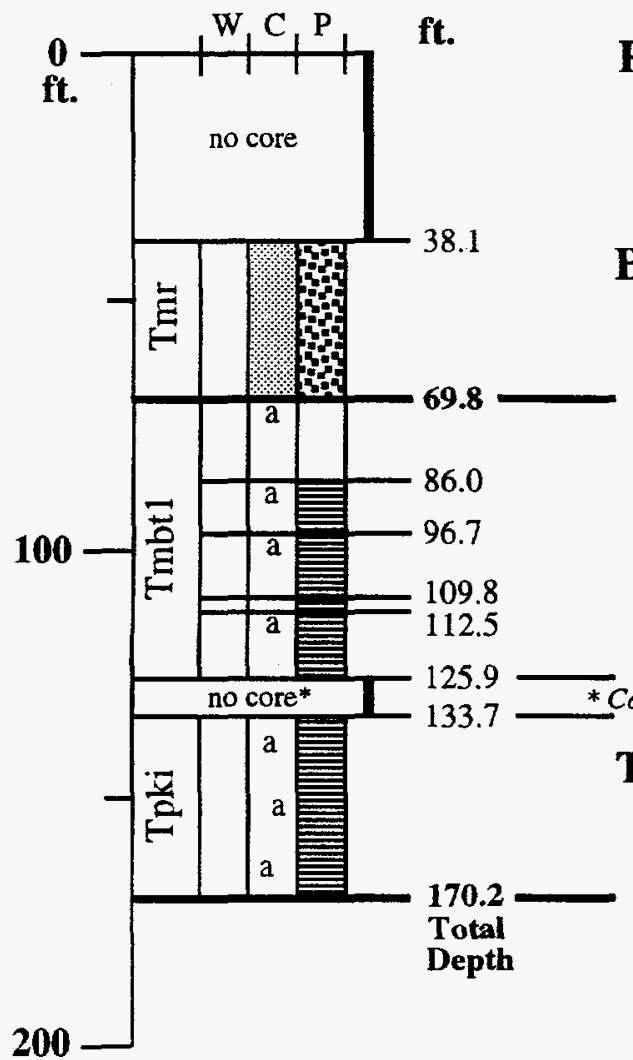

\section{Zones of crystallization (C)}

Devitrified / Devit. + vapor-phase mins.

Vitric / Vitric + vapor-phase mins.

Altered (a) / to clay (c) / to zeolite (z)

\section{Phenocryst content (P)}

greater than 10 percent

$5-10$ percent

less than 5 percent

\section{Rainier Mesa Tuff (Tmr) -}

Nonlithified pyroclastic-flow deposit: $38.1-69.8 \mathrm{ft}$

Matrix, which changes downward from pale yellowish brown to pinkish white, contains distinctive colorless, bubble-wall glass shards. Pumice clasts (10-20 percent) are vitric, colorless, white, light brown, or brownish orange. Crystals (10-15 percent) include qtz, plag, san, and bio.

\section{Bedded Tuff (Tmbt1) -}

69.8-86.0 ft: Nonlithified fallout tephra. White, vitric pumice lapilli and volcanic lithic clasts. Moderately sorted, lithic content increases from about 5 percent to about 20 percent upward, pumice clasts are typically less than $3 \mathrm{~mm}$ diameter. Grades upward into a light brown paleosol (69.8-74.0 ft). 86.0-96.7 ft: Nonlithified pumice-rich fallout. Moderately well sorted, normally graded. Pumice grades upward from less than $5 \mathrm{~mm}$ to less than $3 \mathrm{~mm}$ diameter. Crystals of feld, qtz, bio. Light brown paleosol from 86.0-91.0 ft. 96.7-112.5 ft: Nonlithified pyroclasticflow (?) deposit. Light brown with glass shards and white pumice less than $5 \mathrm{~mm}$. Crystals of feld, qtz, bio. Pumice-rich fallout from 109.8 to $112.5 \mathrm{ft}$. 112.5-125.9 ft: Nonlithified pyroclastic-flow (?) deposit. Medium brown with glass shards and 10-20 percent white pumice, most less than $5 \mathrm{~mm}$. Crystals of feld, qtz, bio. Poorly consolidated below $118.0 \mathrm{ft}$.

* Core run marker notes lithified material at $127.4 \mathrm{ft}$.

\section{Tuff Unit "x" (Tpki) -}

Lithified pyroclastic-flow deposit: 133.7 ft-Total Depth

Pumice clasts (10-15 percent), white to pale yellowish or greenish (zeolitized?), in a brownish gray altered matrix. Volcanic lithic clasts (5-7 percent) are dark gray, dark reddish gray, or medium light gray. 


\section{Borehole :USW NRG-7/7A}

\section{Zones of welding $(W)$}

Moderately to Densely (o-lithophysae)

Partially to Moderately

Non- to Partially

Nonwelded

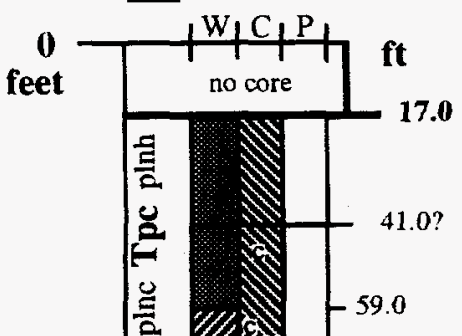

Data Tracking Number: GS940408314211.020

\section{Zones of crystallization $(C)$}

Devituified/Devit. + vapor-phase mins.

Phenocryst content (P)

greater than 10 percent

\section{$5-10$ percent}

less than 5 percent

\section{Tiva Canyon Tuff (Tpc)-}

Crystal-poor lower nonlithophysal zone (pln) (17.0-69.7):

17.0-41.0?-hackly subzone ( $p l n h)$ - Lower contact gradational from 29.0-45.3. Matrix is pale red (10R5/2 to 10R6/2) grading downward to pale brown (5YR5/2). 3-5 percent pumice clasts, gray (N4), devitrified and vapor-phase altered or spherulitic, and grayish pink (5R7/2) and argillic (most less than $20 \mathrm{~mm}$ ). $3-4$ percent 7.0 phenocrysts include feld and bio. Abundant rough, subborizontal fractures. Less than 1 percent lithophysae above 19.2. 41.0?-69.7 columnar subzone (plnc)- Matrix is light brownish gray (5YR6/1) grading downward to pinkish gray (7.5YR7/1). 5-15 percent pumice clasts define foliation, gray (N5) to grayish red (5R4/2), devitrified, locally vapor-phase altered, mostly pink (5R7/6) and argillic below 66.3. 3-4 percent phenocrysts of feld and bio. Moderately welded with remnant shard texture below 59.0. Moderately smooth fractures. Crystal-poor vitric zone (pv) (69.7-102.7):69.7-79.2 \pm 0.8 moderately welded subzone ( $p v 2$ )- Glass shards, moderate brown (5YR5/6) grading downward to dark grayish brown (7.5YR3/1) in light brown $69.7(7.5 \mathrm{YR} 6 / 4)$, partly devit. matrix. 10 percent pumice, white (vitric) to pinkish gray $(5 R 7 / 2$, altered). Welding .8 decreases downward. 79.2 \pm 0.8 -102.7 non -to partially welded subzone ( $p v 1)$. Black (N1) bubble-textured glass shards in pinkish gray (5YR7/2) to light gray (N8) vitric to partly devitrified matrix. Matrix foliation decreases downward. 3 percent pumice as above.

100

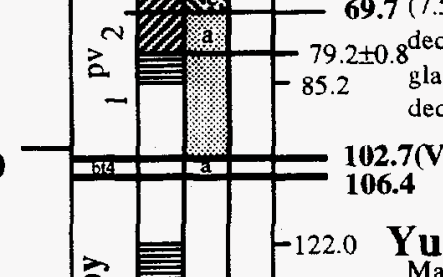

Bedded tuff (Tpbt4) - Pumice-rich fallout, white (N9) grading upward into altered, light brown (5YR6/6) paleosol. Upper and lower contacts are sharp.

Yucca Mountain Tuff (Tpy) -

Matrix grades downward from light brown (5YR6/4) to grayish orange pink (5YR7/2) to medium light gray (N6-N7). Glass shards are coloriess to black with bubble textures. 1.3 percent purnice clasts, vitric (medium gray-N5) to altered (moderate orange-pink-10R 7/4, 5YR8/4; very pale orange-10YR8/2; light brown-5YR6/4). Less than 1 percent phenocrysts include feld. Lower contact in nonrecovered interval.

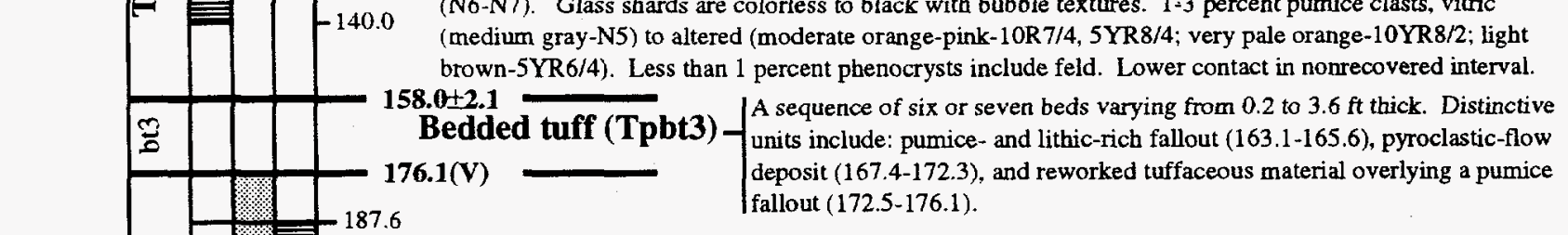

\section{Pah Canyon Tuff (Tpp) -}

Matrix is moderate orange-pink (5YR8/4 to $5 Y R 7 / 4$ to $10 \mathrm{R} 7 / 4$ ) grading downward to very pale orange (10YR8/2), pinkish gray (5YR8/1), and grayish orange-pink (10R8/2). Phenocrysts include feld, bio, and cpx. Variations in pumice size. amount. and color indicate flow unit breaks at 187.6. 204.6 $\pm 0.8,226.3 \pm 1.1$, and 252.0. Pumice (typically 10 to $50 \mathrm{~mm}$. but up to $200 \mathrm{~mm}$ diameter) varies downward: pale yellowish brown (10YR6/2); grayish orange (10YR7/4) with feld; grayish orange and dark yellowish orange (10YR6/6) with feld and bio; dark yellowish orange and moderate yellowish brown (10YR5/4) with feld and bio; grayish pink $(5 Y R 8 / 1)$ and white (N9).

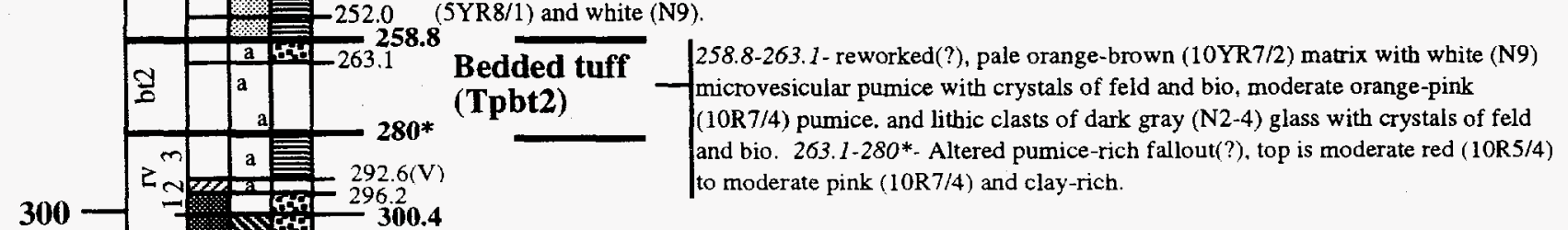

\section{Topopah Spring Tuff (Tpt) -}

\section{Crystal-rich vitric zone (rv) $(280 *-300.4): *$-see note on cover page}

$280^{*}-292.6$ non-to partially welded subzone $(n 3)$ - Matrix grades downward from light brown $(5 \mathrm{YR} 5 / 6)$ to moderate brown ( 5 YR 4/6) and gradually decreases in amount from 70 to 50 percent before decreasing sharpiy to 20 percent at 290 . Vitric pumice clasts are light gray (N6-N8), $10-30$ percent above 290,70 percent below 290. Phenocrysts include feld. (oxy)bio, and cpx.

292.6-296. 2 moderately welded subzone $(r v 2)$. Deformed, vitric, pumice clasts ( 80 percent), moderate yellowish brown (7.5YR4/4) to light gray (N7). Volcanic lithic clasts (15-20 percent) are grayish red (5R 4/2) to medium light gray (N6), commonly with thin opal coating.

296.2-300.4 vitrophyre subzone ( $r v 1)$ - Dark reddish brown (2.5YR3/2) glass with 2-3 percent grayish black (N2). vitric pumice clasts. $12-15$ percent phenocrysts include feld. (oxy)bio. cpx 


\section{Borehole :USW NRG-7/7A}

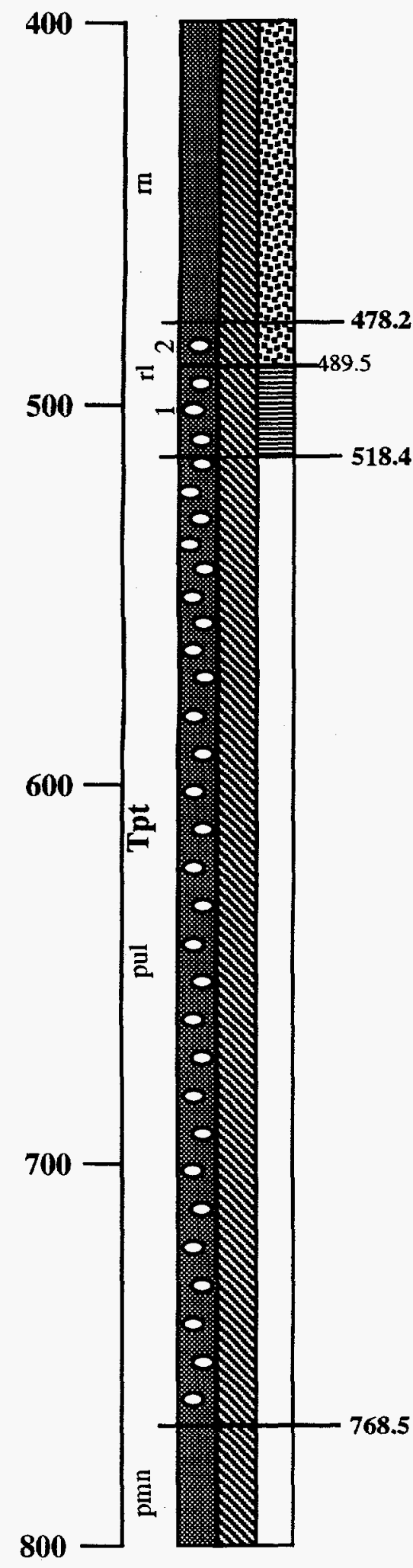

Crystal-rich nonlithophysal zone (rn) (300.4-478.2):

Vapor-phase altered pumice clasts (10-15 percent, locally 5-7 percent) are corroded, mostly less than 30 $\mathrm{mm}$ (up to $45 \times$ greater than $80 \mathrm{~mm}$ ) above about 380 and mostly greater than $30 \mathrm{~mm}$ (up to greater than $80 \mathrm{~mm}$, width of the core) below. Pumice clasts grayish red (10R4/2), pale red (10R6/2), white (N9), and light gray to very light gray (N7 to N8). Phenocrysts include feld, oxybio, rare cpx, and rare bbld (?). Matrix grades downward from brownish gray and moderate brown (5YR4/1 and 5YR3/4) to pale red (10R6/2) to pale reddish brown and light brown (10R5/4 and 5YR56/4). Matrix contains white (N9) streaks of vapor-phase minerals. Degree of devitrification and vapor-phase mineralization increases downward, zone of intense vapor-phase mineralization at about 332-360.

Crystal-rich lithophysal zone (rl) (478.2-518.4):

478.2-489.5 cystal-rich lithophysal subzone (rl2) - Lithophysae (1-3 percent) up to $42 \times 37 \mathrm{~mm}$. Vapor-phase altered pumice clasts (about 10 percent) are corroded, most less than $40 \mathrm{~mm}$ (up to greater than $80 \mathrm{~mm}$, width of the core), white to very light gray (N9 to N8) or rarely pale red (10R6/2). Phenocrysts (10 percent) include feld, oxy bio, and rare altered cpx. Matrix is light brown (5YR5/6) with white (N9) streaks of vapor-phase minerals.

489.5-518.4 crystal transition subzone (rl1) - Phenocrysts decrease downward from 10 percent to 23 percent, and include feld, oxybio, and rare altered cpx. Lithophysae (5 percent at top, 10-15 percent downward) are mostly less than $35 \mathrm{~mm}$ (up to $39 \times 55 \mathrm{~mm}$ ), and have very light gray (N8) rims. Pumice clasts ( 10 percent), most less than $40 \mathrm{~mm}$ (up to $24 \mathrm{x}$ greater than $80 \mathrm{~mm}$, width of core), are pale brown (5YR5/2) and white (N9). Matrix is grayish orange-pink (5YR7/2) to very light gray (N8).

Crystal-poor upper lithophysal zone (pul) (518.4-768.5):

Lower contact gradational from 763-780. Lithophysae range from 2-3 percent to 15-25 percent, mostly greater than 10 percent above about 570 . Lithophysae are mostly less than $40 \mathrm{~mm}$ (up to 60 $\mathrm{mm}$ ) above about 570 , mostly less than $25 \mathrm{~mm}$ (up to $50 \mathrm{~mm}$ ) below, with pinkish gray (5YR8/1) rims. Up to 25 percent spots in matrix that are pinkish gray (5YR8/1). Pumice clasts (5-7 percent at top of unit) decrease downward, pumice textures absent below about 610 . Pumice clasts are mostly less than $30 \mathrm{~mm}$ (up to greater than $80 \mathrm{~mm}$. width of the core), pale brown (5YR5/2) to moderate brown (5YR4/4). Phenocrysts (2-3 percent) include feld and (oxy)bio. Matrix grades downward from grayish orange pink (5YR7/2) to pale red purple and moderate orange pink (5RP6/2 and $10 \mathrm{YR} 7 / 4)$ to a variable mixture of red purple (5RP5/2) and pale red (10R6/3).

\section{Crystal-poor middle nonlithophysal zone (pmn) (768.5-877.6):}

768.5-811.6 upper subzone (pmn3) - Less than 1 percent lithophysae above 785. Matrix is light brown (5YR6/4) with 1-5 percent pinkish gray (5YR8/1) spots. Phenocrysts (1-2 percent) include feld and (oxy)bio. Lithic clasts (less than 1 percent) include very light gray to light brownish gray (N8 to 5YR6/1), most less than $10 \mathrm{~mm}$. 


\section{Borehole :USW NRG-7/7A}

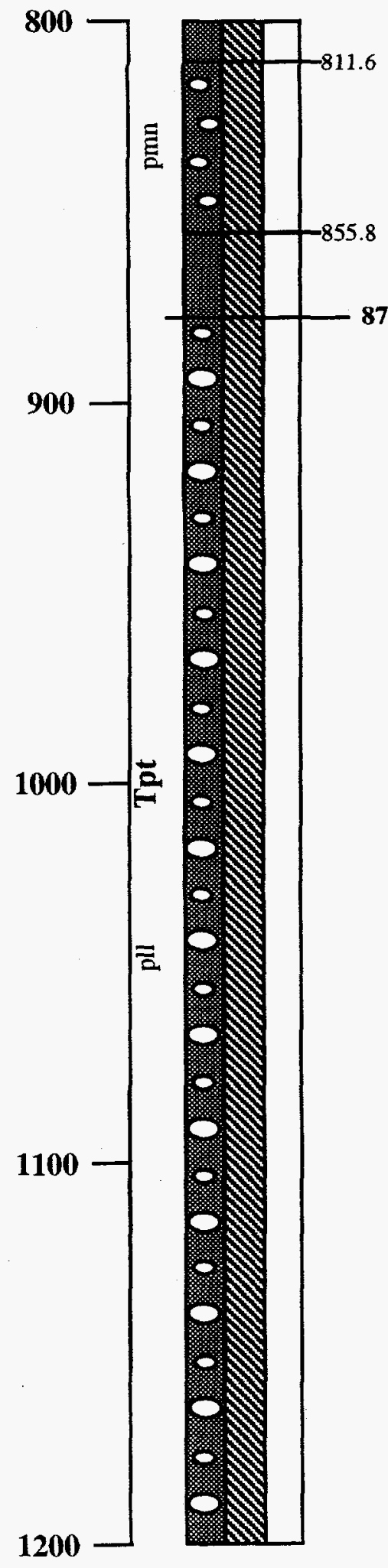

811.6-855.8 lithophysae bearing subzone (pmn2) - 1-3 percent lithophysae, most less than $40 \mathrm{~mm}$ (up to $47 \times 63 \mathrm{~mm}$ ), with 5-15 mm pinkish gray (5YR8/1) rims. Matrix is light brown (5YR6/4) with 2-5 percent pinkish gray (5YR8/1) spots. Phenocrysts (1-2 percent) include feld and (oxy)bio. Less than 1 percent (locally up to 2 percent) volcanic lithic clasts, very light gray (N8) or light brownish gray (5YR6/1), most less than $10 \mathrm{~mm}$.

855.8-877.6 lower subzone ( $p m n 1$ ) - Matrix is light brown (5YR6/4) with grayish orange pink to light gray (5YR7/2 to N7) streaks and rims on high-angle fractures. Phenocrysts (1-2 percent) include feld. Less than 1 percent light gray (N7) volcanic lithic clasts. Less than 1 percent pumice clasts, pinkish gray (5YR8/1), most less than $15 \mathrm{~mm}$.

\section{Crystal-poor lower lithophysal zone (pll) (877.6-1228.5):}

Lower contact is gradational from 1224-1235. Core is predominantly rubble with large unrecovered intervals suggesting lithophysae larger than the core diameter $(80 \mathrm{~mm})$ are present. Core contains less than 1-3 percent visible lithophysae, most less than $25 \mathrm{~mm}$, with grayish orange pink (5YR7/2) rims (generally 1-5 mm wide). Matrix is a variable mixture of light brown (5YR5/4) and pale red (5R6/2), with 10-15 percent grayish orange pink (5YR7/2) spots (up to $35 \mathrm{~mm}$ ) and rims on lithophysae. Pumice clasts ( $1-5$ percent above about $1150,5-10$ percent between about $1150-1200$, 1-4 percent below about 1200) are pinkish gray (5YR8/1) to light brownish gray (5YR6/1) and rarely pale yellowish brown (10YR6/2), mostly less than $25 \mathrm{~mm}$ (up to $9 \times 48 \mathrm{~mm}$ ). Lithic clasts (1-5 percent) are mostly very light gray (N8). Phenocrysts (1-2 percent) include feld and rare (oxy)bio. 
Borehole : USW NRG-7/7A

\section{Data Tracking Number: GS940408314211.020}

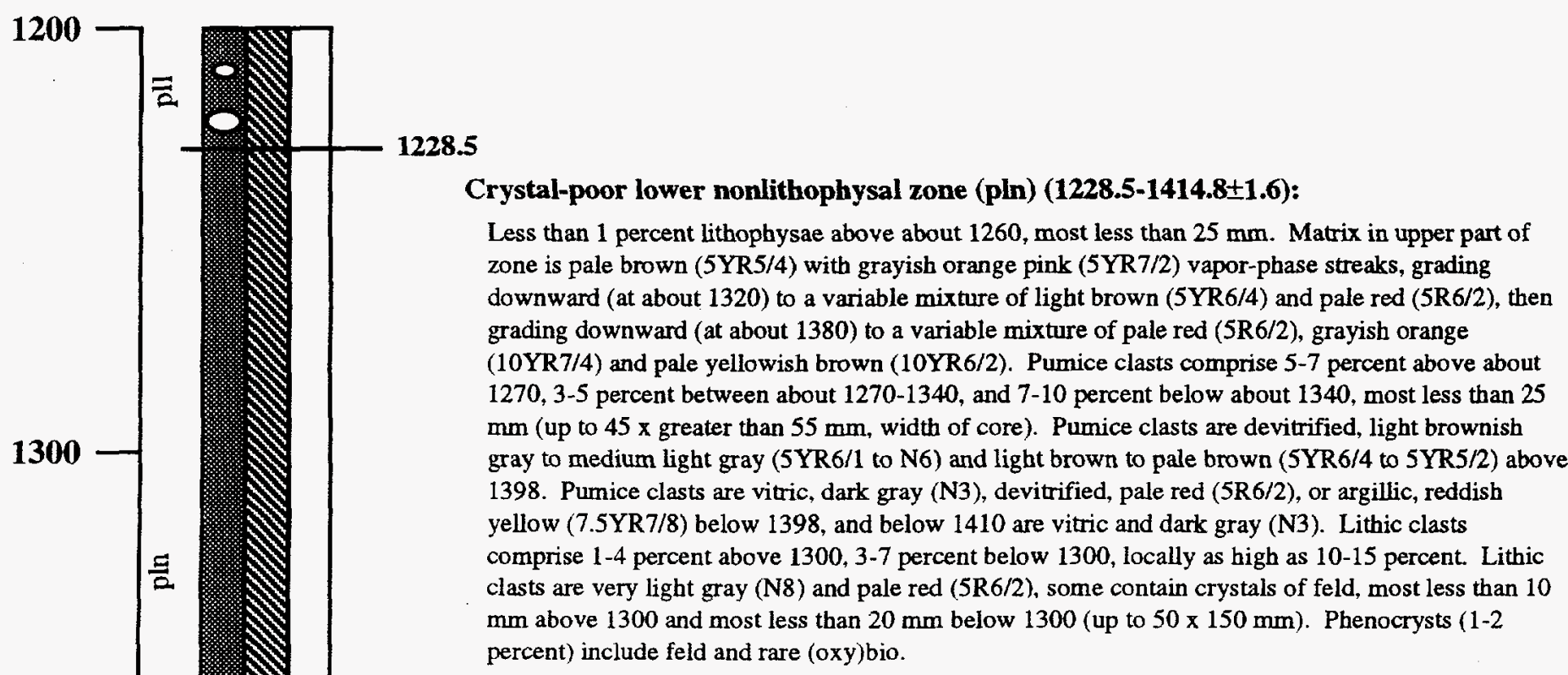

Crystal-poor vitric zone (pv) (1414.8 $\pm 1.6-1493.6 \pm 0.9)$ :

1414.8 $\pm 1.6-1457.0$ vitrophyre subzone ( $p v 3)$ - Grayish black (N2) glass with light brown (5YR5/4) spherulites. Lithic clasts (5-7 percent near top, 7-10 percent near base) are very light gray (N8) and grayish red (10R4/2), most less than $10 \mathrm{~mm}$ (up to $85 \mathrm{x}$ greater than $55 \mathrm{~mm}$, width of core).

Phenocrysts (1-2 percent) include feld.

1457.0-1474.6 moderately welded subzone ( $p v 2)$ - Matrix grades downward from a mixture of grayish black (N2) and reddish yellow (7.5YR7/6) to pinkish gray (7.5YR8/2) with grayish black

(N2) glass shards. Pumice clasts (10-15 percent) are vitric and grayish black (N2) or grayish orange

1414.8 1 1.6 ( $7.5 \mathrm{YR} 7 / 4)$, most less than $30 \mathrm{~mm}$ (up to $20 \times 51 \mathrm{~mm}$ ). Lithic clasts $(5-7$ percent) are very light gray (N8), grayish red (10R4/2), and grayish brown (5YR4/4), most less than $10 \mathrm{~mm}$. Phenocrysts (1-2 percent) include feld.

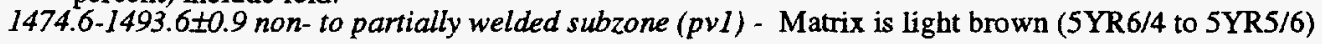
with grayish black (N2) glass shards at top to grayish yellow (5Y8/4) at base. Pumice clasts (10-20

1457.0 percent) are altered and light gray (N7) at top and grayish orange pink (10R8/2) at base, most less than $15 \mathrm{~mm}$ (up to $46 \times$ greater than $55 \mathrm{~mm}$, width of core). Lithic clasts (5-7 percent at top, 10-15 percent at base) are grayish black (N2), light brownish gray (5YR6/2), and rarely moderate orange pink

1474.6 (10R7/4) and light brown (5YR5/6), most less than $15 \mathrm{~mm}$ (up to $48 \times 50 \mathrm{~mm}$ ). Phenocrysts (1-2 percent) include feld and rare qtz (?) and (oxy)bio.

1493.0(V)

1500

1498.0(V)

1511.6

Bedded tuff _ Fallout deposit. Pumice clasts (75-85 percent) are white (N9), pinkish (Tpbt1)

1513.4 Total Depth gray (5YR8/1) and grayish yellow (5Y8/4), most less than $5 \mathrm{~mm}$. Lithic clasts (15-25 percent) are dark gray (N3) and grayish red (10R3/2), most less than $3 \mathrm{~mm}$. Phenocrysts (2-5 percent) include feld, qtz, (oxy)bio.

\section{Calico Hills Formation (Tac) -}

1498.3 $\pm 0.8-1511.6$ pyroclastic flow deposit - Matrix is grayish orange pink (5YR7/2 to 5YR8/3). Pumice clasts (15-20 percent) are grayish yellow to moderate yellow (5Y8/4 to 5Y7/6) or light gray (N7), most less than $15 \mathrm{~mm}$ (up to $7 \times 27 \mathrm{~mm}$ ). Lithic clasts (3-5 percent) are dark gray (N3 to N4) or dark reddish brown (10R3/4), most less than $5 \mathrm{~mm}$. Phenocrysts (1-3 percent) include feld, qtz, and (oxy)bio.

1511.6-1513.4(TD) fallout deposit - Inversely graded. Pumice clasts (85-90 percent) are pinkish gray (5YR8/1) and grayish yellow to moderate yellow green (5Y8/4 to 5GY7/4), most less than $3 \mathrm{~mm}$ above 1512.3 and less than $1 \mathrm{~mm}$ below. Lithic clasts ( $7-10$ percent) are dark reddish brown to grayish red ( $10 \mathrm{R} 3 / 4$ to 5R4/2), most less than $3 \mathrm{~mm}$ above 1512.3 and less than $1 \mathrm{~mm}$ below. Phenocrysts (1-3 percent) include feld, qtz, and (oxy)bio. 